\title{
Production, consumption, marketed surplus and disposal pattern of milk in Andhra Pradesh
}

\author{
Patibandla Lakshmipriya, Raju R, Smita Sirohi, AK Chauhan, PN Raju and Gopal Sankhala
}

Received: 13 September 2018 / Accepted: 15 January 2019 / Published online: 18 April 2019

(C) Indian Dairy Association (India) 2019

\begin{abstract}
The present study investigated production, marketed surplus, consumption and disposal pattern of milk in Andhra Pradesh. The study covered 160 milk producers selected randomly from eight village dairy cooperatives which were post-stratified into small, medium and large herd size category. The study revealed that Overall average milk production was higher for member households (42.15 litres) as compared to non-member households (24.99 litres), respectively. Overall average milk consumption per day per household was lower in the member group (1.51 litres) than non-member group (2.06 litres), respectively. The average quantity of marketed surplus of milk per day per household was higher in the member group (40.64 litres) as compared to the non-member group (22.93 litres), respectively. Out of total quantity of milk disposed off per day by the member households, 96.21 per cent was disposed to dairy cooperatives followed by 2.84 per cent to milk vendors, 1.03 per cent to tea shops and only 0.91 per cent to consumers directly. Similarly, for non-member households, 80.50 per cent was disposed to dairy cooperatives followed by 12.88 per cent to private dairies, 2.49 per cent to milk vendors, 2.11 per cent to tea shops and only 2.03 per cent to consumers directly in the study area.
\end{abstract}

Patibandla Lakshmipriya ( $\square$ )

ICAR-National Dairy Research Institute, Karnal-132 001, Haryana, India

E-mail: lakshmip.patibandla@gmail.com

Raju R

ICAR-Central Soil Salinity Research Institute, Karnal-132 001

Haryana, India

Smita Sirohi, AK Chauhan, PN Raju and Gopal Sankhala ICAR-National Dairy Research Institute, Karnal-132 001, Haryana, India
Keywords: Consumption, Milk production, Marketed surplus and disposal pattern

\section{Introduction}

India is the largest producer of milk among the world's milk producing nations with an annual output of 155.49 million tonnes, contributing about 18.5 per cent in the global milk production (NDDB, 2017). Dairy development in India has been acknowledged world over as one of the modern India's most successful developmental programme. Indian dairymen are aware of the potentialities of scientific management of dairy animals in raising their standard of living. The success of dairy development programme has given them a way that dairying can be as profitable as any other vocation. The Operation Flood Programme is an integrated programme of production, processing and marketing of milk and milk products which is being implemented in the country since July, 1970. The overall aim of this programme is to improve the dairy farmer's income and productivity of animals and make availability of milk and milk products at reasonable prices to the urban consumers. Milk being a perishable commodity, it cannot be marketed individually. Due to this inconvenience, milk producer's cooperative societies have emerged as most viable institutions for milk procurement in rural areas. In India, about 198 dairy cooperative milk unions have covered 5.83 million farmers under 1,70,992 village level dairy cooperative societies up to march, 2016. The daily procurement of milk by dairy cooperative milk unions has reached 42.55 million kgs per day and the sale of liquid milk by them was 32 million litres per day in 2015-16. The department of Animal Husbandry, Dairying and Fisheries for the first time organized "National milk day" on $26^{\text {th }}$ Nov, 2016 to emphasise on promotion of dairy activities including non-operation flood areas by building up of cooperatives, restructuring of sick dairy cooperative milk unions and creation of infrastructure in the states for production of quality milk and milk products.

Andhra Pradesh is predominately an agricultural state with an excellent potential for milk production. Under operation flood- ${ }^{22}$, the state government established a separate dairy development department i.e. Andhra Pradesh Dairy Development Cooperative Federation (APDDCF) as a part of the state Ministry of Food and 
Agriculture which came into existence on April 2, 1974 as the apex body to cover larger areas in the state having 3 tier Anand pattern cooperative structure. The main objective of APDDCF is to develop dairy value chain with primary focus on milk procurement by organized sector and it is nodal agency for implementing dairy development scheme on behalf of Government and is involved in formulating dairy development policies. The APDDCF is manufacturing milk products such as whole milk powder, baby food and cheese butter. It has brought a silent economic revolution in the rural areas, creating a new hope for eliminating poverty and unemployment in rural areas. To bring the white revolution in the state which is an integral part of the rural development, this corporation has concentrated more on modem technical inputs like, quality of crossbreed cattle, better quality of feed, etc., in order to increase the production of milk.

\section{Materials and methods}

Multistage stratified sampling technique was adapted for selecting the sample households for the study. The data was collected from 160 dairy farmers of Andhra Pradesh, comprising 80 each from Guntur and chittoor districts. Out of 80 farmers from each district, 40 were members and 40 were non-members of dairy cooperatives. The primary data was collected from respondents during the period of November to February, 2018. The households were then post stratified into three categories on the basis of their herd size as per standard animal units (SAUs) by using cumulative square root frequency method. Based on the herd size categories in the present study, the member households were categorized into 19, 26 and 35 as small, medium and large farmers, respectively and non-members were categorized into 27 , 33 and 20 as small, medium and large farmers, respectively. The data collected have been analysed using different statistical measures and interpreted across herd-size categories of milk producers as well as overall.

The marketed surplus of milk was the quantity of milk sold after meeting the family requirements of milk for consumption and for conversion into other milk products like butter milk, curd, etc. Thus the marketed surplus of milk was calculated as

Marketed Surplus $=$ Total milk production - Total milk consumption

Table 1 Average production, consumption and marketed surplus of milk by groups across herd size categories (Litres/day/household)

\begin{tabular}{llllllc}
\hline $\begin{array}{l}\text { Herd Size } \\
\text { Category }\end{array}$ & $\begin{array}{l}\text { Member } \\
\text { Total } \\
\text { production }\end{array}$ & Consumption & $\begin{array}{l}\text { Marketed } \\
\text { Surplus }\end{array}$ & $\begin{array}{l}\text { Non-member } \\
\text { potal }\end{array}$ & Consumption & $\begin{array}{c}\text { Marketed } \\
\text { Surplus }\end{array}$ \\
Small & $17.63(100.00)$ & $1.21(6.86)$ & $16.42(93.14)$ & $14.23(100.00)$ & $1.85(13.00)$ & $12.38(87.00)$ \\
Medium & $33.63(100.00)$ & $1.50(4.46)$ & $32.13(95.54)$ & $26.99(100.00)$ & $2.12(7.85)$ & $24.87(92.15)$ \\
Large & $61.79(100.00)$ & $1.77(2.86)$ & $60.02(97.14)$ & $36.22(100.00)$ & $2.25(6.25)$ & $33.97(93.79)$ \\
Overall & $42.15(100.00)$ & $1.51(3.58)$ & $40.64(96.42)$ & $24.99(100.00)$ & $2.06(8.25)$ & $22.93(91.75)$ \\
\hline
\end{tabular}

Figures in parentheses indicate percentage of average milk production
Disposal pattern of milk is retention of liquid milk and conversion of milk into different milk products at the farm level and remaining part out of total milk production that is available for sale as liquid milk in market. Information was collected on quantity of milk consumed at home, the quantity of milk sold and the agency to whom milk sold like cooperatives, private dairies, milk vendors or directly to consumers and average price realized and the reasons for selling milk to the particular agency. The relative share of each marketing agency in the marketed surplus of milk was also worked out using tabular analysis.

\section{Results and discussion}

Milk, unlike most other farm products, is perishable in nature and as such requires quick disposal or conversion into milk products. Therefore, it is of vital importance to examine the production, consumption and marketed surplus of milk on different herd size categories. Moreover, there is also need to identify the category of milk producers who contribute maximum share to the marketed surplus of milk. An attempt has been made in the present study to determine the production, consumption, marketed surplus and disposal pattern of milk by the member and non-member households.

\section{Milk production}

A close perusal of Table 1 revealed that, overall average milk production was higher for member households (42.15 litres) as compared to non-member households (24.99 litres). This could be due to the rearing of superior quality of animals and adoption of better management practices. Among various herd size categories, the average milk production per household was lowest in small herd size category (17.63 litres) and highest in large herd size category (61.79 litres) across member households whereas it was observed to be lowest in small herd size category (14.23 litres) and highest in large herd size category (24.99 litres) across non-member households. The average milk production per household increases with increase in the herd size in both the member and non-member households. Similar findings were observed in the earlier studies conducted by Meena (2008) and Ravishankara (2014).

\section{Milk consumption}


A perusal of the Table 1 revealed that overall average milk consumption per day per household was lower in the member group ( 1.51 litres) than non-member group (2.06 litres). It may be observed from the Table 5.14 that average per cent consumption of milk to total production per day per household was lower in member households (3.58 per cent) than the non-member households ( 8.25 per cent). The relatively lower per cent milk consumption in member households could be due to generate more marketed surplus in view of remunerative prices being offered to milk producer member. Among various herd size categories, the average milk consumption per day per household was lowest in small herd size category and highest in large herd size category in both the member and non-member groups. Further, the level of milk consumption increases with increase in herd size in both the member and non-member groups. Similar findings were also reported by Meena (2008) and Ravishankara (2014).

\section{Marketed surplus of milk}

It may be observed from the Table 1 that average quantity of marketed surplus of milk per day per household was higher in the member group (40.64 litres) as compared to the non-member group (22.93 litres). The per cent marketed surplus of milk to total production was higher in the member group ( 96.42 per cent) as compared to the non-member group ( 91.75 per cent) as presented in the Table 5.14.
The higher per cent marketed surplus of milk observed in member group could be attributed to better marketing facilities together with remunerative price being offered to milk producers. Among various herd size categories, the average daily marketed surplus of milk was lowest in small herd size category (16.42 litres) and highest in large herd size category (60.02 litres) across member households. In the case of non-member households, it was also lowest in small herd size category (12.38 litres) and highest in large herd size category (33.97 litres). Further, the per cent marketed surplus of milk to total production was also observed to be increase with increase in herd size categories in both the member and non-member groups. Similar findings were observed in the earlier studies conducted by Meena (2008) and Ravishankara (2014).

\section{Disposal pattern of marketed surplus}

The success of any enterprise largely depends on availability of marketing facilities to the producers for disposal of their produce, especially for that enterprise whose produce is highly perishable. An efficient market structure provides remunerative price to the producer and makes produce available at a reasonable price to the ultimate consumer. An efficient market makes the price spread narrow between consumers and producers by economising the handling operations and reducing the margin of the middlemen.

Table 2 Disposal pattern of milk among both member and non-member groups

\begin{tabular}{|c|c|c|c|c|c|c|c|c|}
\hline \multirow{2}{*}{$\begin{array}{l}\text { Mode of } \\
\text { disposal }\end{array}$} & \multicolumn{4}{|l|}{ Members } & \multirow{2}{*}{$\begin{array}{l}\text { Non- } \\
\text { Small } \\
\end{array}$} & \multicolumn{3}{|l|}{ Members } \\
\hline & Small & Medium & Large & Oveall & & Medium & Large & Oveall \\
\hline Total quantity & $\begin{array}{l}16.42 \\
(100.00)\end{array}$ & $\begin{array}{l}32.13 \\
(100.00)\end{array}$ & $\begin{array}{l}60.02 \\
(100.00)\end{array}$ & $\begin{array}{l}40.64 \\
(100.00)\end{array}$ & $\begin{array}{l}12.38 \\
(100.00)\end{array}$ & $\begin{array}{l}24.87 \\
(100.00)\end{array}$ & $\begin{array}{l}33.97 \\
(100.00)\end{array}$ & $\begin{array}{c}22.93 \\
(100.00)\end{array}$ \\
\hline disposed (litres & s/day) & & & Organised & I sector & & & \\
\hline $\begin{array}{l}\text { 1. Dairy } \\
\text { cooperative } \\
\text { societies }\end{array}$ & $\begin{array}{l}15.21 \\
(92.63)\end{array}$ & $\begin{array}{l}30.05 \\
(93.53)\end{array}$ & $\begin{array}{l}57.68 \\
(96.10)\end{array}$ & $\begin{array}{l}38.70 \\
(95.21)\end{array}$ & $\begin{array}{l}9.06 \\
(73.19)\end{array}$ & $\begin{array}{l}20.58 \\
(82.75)\end{array}$ & $\begin{array}{l}27.69 \\
(81.51)\end{array}$ & $\begin{array}{l}18.46 \\
(80.50)\end{array}$ \\
\hline 2. Private dairy & $0(0.00)$ & $0(0.00)$ & $\begin{array}{l}0(0.00) \\
\text { Unorganised } \mathrm{s}\end{array}$ & $\begin{array}{l}0.00(0.00) \\
\text { ectors }\end{array}$ & $2.25(18.17)$ & $2.68(10.78)$ & $4.35(12.81)$ & $2.95(12.88)$ \\
\hline 3. Milk vendor & $0.47(2.86)$ & $1.26(3.92)$ & $1.45(2.42)$ & $1.16(2.84)$ & $0.51(4.12)$ & $0.56(2.25)$ & $0.63(1.85)$ & $0.57(2.49)$ \\
\hline $\begin{array}{l}\text { 4. directly to } \\
\text { consumers }\end{array}$ & $0.36(2.19)$ & $0.39(1.21)$ & $0.42(0.70)$ & $0.37(0.91)$ & $0.12(0.97)$ & $0.56(2.25)$ & $0.78(2.30)$ & $0.47(2.03)$ \\
\hline $\begin{array}{l}\text { 5.Tea shops } \\
\text { and others }\end{array}$ & $0.38(2.31)$ & $0.43(1.34)$ & $\begin{array}{l}0.47(0.78) \\
\text { Place of sale }\end{array}$ & $0.42(1.03)$ & $0.44(3.55)$ & $0.49(1.97)$ & $0.52(1.53)$ & $0.48(2.11)$ \\
\hline $\begin{array}{l}\text { Sale within } 15.5 \\
\text { the village }\end{array}$ & $\begin{array}{l}7(94.82) 30 \\
(1+2+4)\end{array}$ & $44(94.74) 58.1$ & $10(96.80) 39.07(9$ & 2) 11.43( & 2.33) 23.8 & 5.78) 32.8 & (96.61) 2 & \\
\hline $\begin{array}{l}\text { Sale outside } \\
\text { the village }\end{array}$ & $\begin{array}{l}0.85(5.18) \\
(3+5)\end{array}$ & $\begin{array}{l}1.69(5.26) \\
\text { Terms and }\end{array}$ & $\begin{array}{l}1.92(3.20) \\
\text { conditions of sale }\end{array}$ & $1.5755(3.8$ & 8) $0.95(7.67)$ & $1.05(4.22)$ & $1.15(3.39)$ & $1.05(4.59)$ \\
\hline $\begin{array}{l}\text { Immediate } \\
\text { cash }(3+5)\end{array}$ & $0.85(5.18)$ & $1.69(5.26)$ & $1.92(3.20)$ & $1.58(3.88)$ & $0.95(7.67)$ & $1.05(4.22)$ & $1.15((3.39)$ & $1.05(4.59)$ \\
\hline Contract $(1+2)$ & $15.21(92.63$ & $30.05(93.53)$ & $57.68(96.10)$ & & $0(95.21) 11.3$ & $1(91.36) 23$. & $26(93$. & 2) $21.41(93.37)$ \\
\hline Credit (4) & $0.36(2.19)$ & $0.39(1.21)$ & $0.42(0.70)$ & $0.37(0.91)$ & $0.12(0.97)$ & $0.56(2.25)$ & $0.78(2.30)$ & $0.47(2.03)$ \\
\hline
\end{tabular}

Figures in parentheses indicate the percentage 
During present investigation, it was observed that both organised and unorganised agencies were operational in the study area. The organized sector includes co-operative societies and private dairies while unorganized sector includes consumer directly, milk vendors, tea shops, hotels and restaurants, etc.

Table 2 depicts the disposal pattern of milk among both member and non-member group households in the study area. A close perusal of table revealed that out of total quantity of milk disposed off per day by the member households, 96.21 per cent was disposed to dairy cooperatives followed by 2.84 per cent to milk vendors, 1.03 per cent to tea shops and only 0.91 per cent to consumers directly. As far as category wise disposal of milk is concerned, small farmers disposed off 92.63 per cent to cooperatives, 2.86 per cent to milk vendors, 2.31 per cent to tea shops and 2.19 per cent to consumers directly. Similarly, the medium farmers disposed off 93.53 per cent to dairy cooperatives followed by 3.92 per cent to milk vendors, 1.34 per cent to tea shops and 1.21 per cent to consumers directly. Whereas large farmers disposed off 96.10 per cent to dairy cooperatives followed by 2.42 per cent to milk vendors, 0.78 per cent to tea shops and 0.70 per cent to consumers directly. Member households were disposed off their milk mainly to dairy cooperative societies and they are selling their milk to private dairies. This is due to provision of proper input services and better remunerative prices offered by the dairy cooperatives in the study area.

As far as place of sale is concerned, mostly milk is disposed off within the village (96.12 per cent) followed by around 3.88 per cent outside the village. This is due to presence of dairy cooperatives in the village itself and reduction in transportation cost.

As far as terms and conditions of sale is concerned, the member households disposed off their milk mainly on contract basis (95.21 per cent) followed by immediate cash (3.88 per cent) and credit (only 0.91 per cent).

A close perusal of Table 2 revealed that out of total quantity of milk disposed off per day by the non-member households, 80.50 per cent was disposed to dairy cooperatives followed by 12.88 per cent to private dairies, 2.49 per cent to milk vendors, 2.11 per cent to tea shops and only 2.03 per cent to consumers directly. As far as category wise disposal of milk is concerned, small farmers

Disposed off 73.19 per cent to co-operatives, 18.17 per cent to private dairies, 4.12 per cent to milk vendors, 3.55 per cent to tea shops and 0.97 per cent to consumers directly. Similarly, the medium farmers disposed off 82.75 per cent to dairy cooperatives followed by 10.78 per cent to private dairies, 2.25 per cent to milk vendors and directly to consumers and 1.97 per cent to tea shops. Whereas large farmers disposed off 81.51 per cent to dairy cooperatives followed by 12.81 per cent to private dairies, 2.30 per cent to consumers, 1.85 per cent to milk vendors and 1.53 per cent to tea shops. Non-member households were disposed off their milk mainly to dairy cooperative societies and private dairies.

As far as place of sale is concerned, mostly milk is disposed off within the village (95.41 per cent) followed by around 4.59 per cent outside the village. This is due to presence of dairy cooperatives in the village itself and reduction in transportation cost.

As far as terms and conditions of sale is concerned, the nonmember households disposed off their milk mainly on contract basis (93.37 per cent) followed by immediate cash (4.59 per cent) and credit (2.03 per cent).

\section{Conclusions}

The average quantity of marketed surplus of milk per day per household was higher in the member group (40.64 litres) as compared to the non-member group (22.93 litres). The per cent marketed surplus of milk to total production was higher in the member group ( 96.42 per cent) as compared to the non-member group ( 91.75 per cent).

Total quantity of milk disposed per day was more for members (40.64 litres) as compared to non-members (22.93 litres).In case of member group dairy farmers, the milk is disposed off around $95.21 \%$ to dairy cooperatives and around $4.78 \%$ to unorganized sectors where as in case of non-member group, the milk is disposed off to dairy cooperatives around $80.50 \%, 12.88 \%$ to private dairy and around $6.63 \%$ to unorganized sectors.

As far as place of sale is concerned, mostly milk is disposed off within the village around 96.12 per cent by members and around 95.41 per cent by non-members. Whereas around 4.59 per cent by members and around 3.88 per cent by non-members disposing their milk outside the village.

As far as terms and conditions of sale is concerned, the member households disposed off their milk mainly on contract basis (95.21 per cent) followed by immediate cash (3.88 per cent) and credit (only 0.91 per cent). Whereas the non-member households disposed off their milk mainly on contract basis (93.37 per cent) followed by immediate cash ( 4.59 per cent) and credit ( 2.03 per cent).

Disposal pattern of marketed surplus among both member and non-member group in the study area had shown preference for organized agencies mainly dairy cooperatives to dispose off their produce. But still some quantity of milk is disposed to unorganized sectors. The reason behind this conclusion was that in case of organized agencies the price of milk is mainly determined by the percentage fat content of the milk incentives for better quality milk and penalties for not meeting minimum acceptable standards were prevalent in the area. In case of 
unorganized agencies, no such practice is followed for determining the price of the milk hence, the milk is sold according to market forces like supply, demand and season. Hence, suitable initiative and measures has to be taken to promote dairy cooperative societies in terms of increasing the number of members in rural areas and providing better incentives for milk producers. So that, large scope existed for dairy co-operative societies to extract milk from non-members those supplying milk to unorganized sectors and also its benefit reaches to all the dairy farmers. In order to increase marketed surplus and strengthen the sustainability of small herd size farmers, herd size has to be increased along with the productivity of the milch animals, organized milk marketing should be promoted and dairy extension services should be strengthened.

\section{References}

Arun Kumar (2003) Economics of Milk Production and Marketed Surplus of Milk in Vellore district of Tamil Nadu. M.Sc. Thesis, ICAR National Dairy Research Institute (Deemed University), Karnal, Haryana, India
Badal PS (1994). Economics of Milk Production and its Disposal Pattern in Gopalganj district of Bihar. M.Sc. Thesis (Unpublished), ICAR National Dairy ResearchInstitute (Deemed University), Karnal, Haryana, India

Meena GL (2008) Impact of Dairy Cooperatives on the Economy of Rural Households in Alwar district of Rajasthan. Ph.D. Thesis , ICAR-National Dairy Research Institute (Deemed University), Karnal, Haryana, India

National Dairy Development Board (NDDB) (2017) Milk production by states, $\quad$ http://www.nddb.coop/English/Statistics/Pages/MilkProduction-States.aspx.

Ravishankara KM (2014) Impact of Dairy Cooperatives Societies on Rural Economy in Mandya district of Karnataka. M.Sc. Thesis (Unpublished), ICAR-National Dairy Research Institute (Deemed University), Karnal, Haryana, India

Rishikanta Singh (2006). Economics of Milk Production and Marketed Surplus in Imphal West district of Manipur. M.Sc. Thesis (Unpublished), ICAR- National Dairy Research Institute (Deemed University), Karnal, Haryana, India 